\title{
Political Economy and Urban Poverty in the Developing Countries: Lessons Learned from the Sudanese Experience
}

\author{
Yasin Abdalla Eltayeb Elhadary \\ University of Khartoum, Department of Geography, Post doctoral USM-Malaysia \\ Universiti sains Malaysia, 11800-Penang, Malaysia \\ Tel: 60-125-996-924Ｅ-mail: yasin@usm.my
}

Narimah Samat

School of Humanities-Geography Section, Universiti sains Malaysia, 11800-Penang, Malaysia

Tel: 60-125-018-834Ｅ-mail: narimah@usm.my

Received: October 18, 2010 Accepted: November 5, 2010 doi:10.5539/jgg.v3n1p63

\begin{abstract}
Urbanization is rapidly growing all over the world with a high rate of growth in the developing countries. Several factors are presumed to be responsible for the unfolding of urban growth and urbanization processes, which include but not limited, massive rural-urban migration, imbalances in the provision of social services, change in land use policy, market liberalization, conflict, wars, natural disasters, and the consequences resulting from deficient economic policies and attendant practices. In a country like Sudan, rapid urban growth has a propensity of culminating in reduction of job opportunities, which is coupled with high cost of living that subjects urban dwellers particularly the vulnerable group to be plunged into deep poverty.

This paper deals with the issue of urban poverty in the developing countries taking Sudan as an example. The overall objective is to uncover the current situation of urban poverty with particular emphasis on its pattern, causes, indicators and the policies adopted for tackling and alleviating urban poverty. By so doing, it is expected that this piece could help in bridging some gaps regarding the understanding and knowledge with regard to urban poverty. The political economy approach is used in order to link political and economic policies at both national and international levels. This approach shows that the urban poor in developing countries tends to be further impoverished mainly as a result of defective economic policies rather than other causative factors. It is believed that the Structural Adjustment Program (SAP) prescribed by the World Bank could be held responsible for pushing a considerable number of urban dwellers into poverty. Since their accession to independence, most of the developing countries are induced by alleged benefits that could accrue from subscribing to western economic policy prescriptions that are in most cases irrelevant to the need of local communities. The establishment of big projects under the pretext of "new development" has always been a political decision that is shaped by the interests of national and international policymakers rather than local priorities and needs.
\end{abstract}

Keywords: Urbanization, Poverty, Political economy, Economic policy and Sudan

\section{Introduction}

Rapid urbanization is on the rise all over the world and is expected to continue in the coming decades characterized by high growth rate particularly in the developing countries. Managing urbanization has become a nightmare for planners and decision makers not only in the developing countries but also in the developed nations. The fundamental question that has not yet been answered is whether urban expansion should be resisted or accepted. At one extreme, there have been those who advocate the need for limiting the growth of cities by any and all means. On the other hand, there are those who welcome it as a means for absorbing the oncoming waves of new migrants (World Bank, 2005). Figures provided by academics, researchers and organizations dealing with urban studies have portrayed the future of urbanization as staggering particularly with regard to developments in the developing countries. According to UNCHS (1996 cited in Samat, 2002) indicated that the urban population in the developing nations has increased from less than 300 million in 1950 to 1.1 billion in 1985 , which is projected to reach 4 billion in 2025 . The average density of the built-up area is 8,000 persons per 
square kilometer and this is envisaged to grow to more than 600,000 square kilometers by 2030 (World Bank, 2005). This means urbanization will continue to grow and the encroachment to non-urban or (rural-agriculture) areas will increase dramatically causing socio-economic and ecological problems. According to UNESC (2007), over 70 per cent of the population in the Pacific sub-region already lives in urban areas whereas the urban population of East and South-East Asia is expected to reach the level of 50 per cent before 2015. The annual change in the developed and developing countries over the period between 1990 and 2000 was $0.6 \%$ and $1.8 \%$ for urban population and $2.9 \%$ and $3.6 \%$ for built-up areas respectively (World Bank, 2005). Under a situation of such a high speed of urban expansion, it is too hard for places like Sudan to fulfill the requirements for of urbanization such as provision of services, infrastructures, job opportunities and housing unless serious practical measures are resorted to.

The ineffective economic policies aggravated by ecological problems like severe drought that affected most of the African Sahel-Belt including Sudan in the mid-eighties has forced thousands of rural people to flee to urban areas. Currently the number of urban dwellers in Sudan has increased from $8 \%$ in the year 1956 up to $29 \%$ in the 2008 (CBS, 2008) or to $40 \%$ (MWSS, 2010) of the total population. As a result, the speedy and spontaneous urbanization process has significantly expanded where currently there are around seventy five cities that have a population more than twenty thousand people each (CBS, 2008).

Much have been said in the literature about poverty and its negative impact on socio-economic life of the rural people without considering state of affairs related to urban poverty. It seems that urban poverty has not been given the attention that it deserves by both academicians and decision makers. The general image with regard to the issue of urban poverty on the part of both laymen and specialists who are urban dwellers is that they enjoy a better life than those who live in the rural areas. Hence there is a need to revise the notion that not all urban people have access to or benefited from the services and facilities offered by city life. As a result of unplanned urbanization urban poverty will continue to increase as always since there is a correlation between urbanization and the prevalence of urban poverty especially in the developing countries. Although there is no reliable data in Sudan on the issue of urban poverty, the existing ones show that more than half of the urban dwellers are living under the poverty line, which is applicable to 90 percent of the total population of the country (Mahran, 2006). In the light of this, the paper attempts to contribute to the knowledge and better understanding of urban poverty by using the situation in Sudan as a case. The objective is to fill the gap particularly in terms of putting urban poverty in the political context and lay the ground for embarking on further research on the subject.

\section{Conceptual framework and analytical approach}

In this paper the practical definition of the urban poverty is quoted from Sen (cited in UNESC, 2007). Sen defines poverty as the deprivation of basic capabilities that provide a person with the freedom to choose the life he or she has reason to value. These capabilities include good health, education, social networks and command over economic resources, and influence decision-making that affects one's life. This appears to be similar to the national definition of poverty in Sudan. According to Ministry of Welfare and Social Security MWSS (2008), poverty is defined as the inability to meet the minimum basic necessities of life for individual and family that preserve or conserve religion, mind, money, and soul. The basic necessities include access to food, clothes, public transportation, owning a house or the ability to rent, availability of potable water, health and educational services, and security of property and life. Both definitions focus on respect to and dignity of the individual, access to income, and services- all of which serve as indictors for measuring poverty. This article considers that income as an important variable for measuring urban poverty because it allows a person to develop his or her capabilities and ensures access to services particularly after the withdrawal of the state from engaging in service provision resulting from the introduction of privatization. The authors are of the view that measuring poverty in terms of income is preferable especially when dealing with the urban poor due to the fact that commanding financial resources enables individuals to access the basics of life like food, services, and housing.

Countries have different approaches for determining what is urban, peri-urban, and sub-urban though some of the factors used to this end could be debatable. Some take population size (e.g. 5000 or more) whereas others consider population density $\left(500\right.$ per $\left.\mathrm{km}^{2}\right)$ or sectoral economic activities (less agriculture, more in services and trade) (Tacoli, 1998). Taking Benin as an example, Tacoli stated that a town is a district with a population of 10 000 inhabitants or more and with at least four among the following establishments like post office, tax office, public treasury, bank, running water supplies, electricity, health centre and secondary school. The authors concur with this notion and are in agreement that any area inhabited by more than ten thousand people should be classified as urban. 
The methodology adopted in this paper could be stated as follows. Generally accurate and up to date data on poverty is considered as a scarce commodity in the developing countries. This paper is based on a review of the fragmented data that are found in academic institutions, UN reports, and the work of some individuals that are interested in the study of poverty (Musa, 2002; Eltayeb, 2003; Mahran, 2006). In addition to the internet sites of governmental institutions that are complemented by observations of researcher in this field. To put urban poverty in the context of faulty and ineffective economic policies, the political economy approach has been adopted as an analytical tool as illustrated in the diagram (Fig 1) that is relevant to the state of urban poverty in the developing countries. The diagram shows that the livelihood of local people is not only affected by national policies such as privatization and price liberalization but also by external policy prescriptions like Structural Adjustment Programme SAP, which entail major constraints in the livelihood of both urban and rural communities. The change in land use from subsistence to cash-crop producing economies or industrial activities has weakened the adaptive mechanisms of rural people and limited their resistance to poverty. National policies often tend to neglect peasant economies of the rural people that stand as the mainstay of their livelihood. This trend is further aggravated by the existence of both environmental hazards such as recurrent drought and man-made disasters taking place in the form of unfolding conflict and war. In order to cope with this, rural people have no option than to flee into urban areas causing huge pressure on the already congested and limited services and infrastructure. As a result, unplanned urbanization has expanded rapidly both spatially and demographically. Urban areas are not well developed to absorb new migrants and provide gainful employment opportunities. Coupled with the lack of capital and other assets characterizing migrants from the rural areas, this situation forces them to join the informal sector as the only available alternative. As a consequence of low wages characterizing the level of income, the urban poor are forced to lead a way of life underpinned by misery under which possibilities of meeting the minimum requirement of human existence could be farfetched.

\section{The political economy approach}

According to Todaro (1989) political economy is concerned with the relationship between politics and economics with particular emphasis on the role of power in economic decision-making in general and the role of the state and international actors in particular. Due to the inequitable distribution of power between the developed north and the south, most of the developing countries have no choice except being "forced" to accept whatever policies are imposed from the West in the form of modernization, privatization, and globalization regardless of their relevance the needs of the local people at the receiving end. For example, rural people in Sudan became subjected to subscribe to the policies of the World Bank since the early 1940s. Under such policies that emphasize modernizing agriculture, large mechanized farming schemes have expanded at the expense of pastoral land in most of the eastern part of Sudan (El Hadary, 2007). It should be noted that unequal distribution of power within a society and related inequalities and disparities are function of state policies, which are usually seen as serving the interests of the more powerful groups (Egemi, 1994).

Following this approach, the urban poor in developing countries in general and Sudan in particular are not only affected by rural-urban migration, high population growth or environmental degradation but also structural processes related to economic policies adopted at both national and international levels. For example changes in land use (privatization) in Sudan under pressure or incentives from the "developed world" should be held responsible for the taking shape and entrenchment of urban poverty. Evidence from the Philippines also supports the line of putting land use change in the context of politics. Philip (1998), in his article on land use conversion in the Philippines, states that the process of conversion of rice land into industrial and urban residence plots represents a political process in two senses: first, policy choices are made relating to the use of land that reflect a particular set of developmental priorities; and second, the facilitation of conversion involves the use of power relations to circumvent certain regulations. Therefore, in view of this perspective urban poverty is an output of the policy and process of changing "rural lands" for urban uses is facilitated by decision makers at the international, national and local levels in order to serve parochial interests.

\section{Political economy and the international policy: Structural adjustment programme (SAP) and privatization}

This section deals with the role of external factors that contributed to urban poverty in the developing countries by taking SAP and its related consequences as a point of departure. As already stated, the livelihoods of local communities in most of the developing world are not only shaped by the economic decisions made at the national level alone but also by externally-based policy drives. Thus poor people in a country like Sudan became victims of policies that were designed to serve the interests of the powerful in both the developed and developing countries. One of these policies with a significant adverse effect on the livelihood of vulnerable groups and aggravated both rural and urban poverty in Sudan is the Structural Adjustment Programme (SAP), which is 
introduced by the World Bank and IMF on the eve of oil crisis of the early-eighties. Up to 1992, around 78 countries have been forced to subscribe to this policy with or without pressure from the World Bank whereby many others like Sudan had introduced essentially the same framework without formal agreements with the Bank (Musa, 2000; Musa, 2002; Maharn, 2006; Dagdeviren, 2006). Price liberalization, privatization, the removal of government subsides, significant devaluation, cuts in public expenditure accompanied by deep public sector retrenchments, relaxation of foreign exchange controls, increase in interest rates to real levels, withdrawal of protectionist measures, introduction of user fees, tight control of credit, and increase in agricultural producer prices are some of the major characteristics of this program (Stein 1992 cited in Musa, 2000).

Mush is said about SAP in escalating poverty and becoming a burden on national governments in the developing countries. In the case of Sudan, Maharn (2006) states that adoption of SAP has resulted in more scarcity, skyrocketing inflation rates, huge budget and balance of payments deficits, economic stagnation, and widespread poverty. In the same vein, Babiker (2006) states that SAP focused on economic growth without addressing how this growth is to be redistributed to the poor, especially the marginalized minorities such as the pastoralists. For Musa (2002), more than half of the population in Sudan lives under the poverty line and five million employees are destitute due to the adoption of SAP. This policy not only affected the vulnerable urban groups who joined the informal sector but also the former government officials who, due to economic liberalization and increase in cost of living, were pushed into poverty. As Musa (2000) stated the so-called structural adjustment and liberalization policies of the IMF and the World Bank have contributed the most in pushing an ever-growing number of working people below the poverty line in all regions of the world.

Privatization, which is adopted by most of the developing countries including Sudan in the early 1990s, is considered as the legal basis for the introduction of SAP. Under the slogan of existing excess labor, better efficient use of resources, reduction of the fiscal burden caused by the state enterprises, and increase output production in term of quantity and quality, the government of Sudan has embarked on privatization. Dagdeviren (2006) states that in Sudan one hundred and seventeen state public enterprises have been privatized, which is a little less than half of those in the service and utility sectors and close to one third and one-fourth in the agricultural and industrial sectors, respectively. It cannot be denied that the role of well-managed privatization is significant in creating competition, enhancing quality, and speeding up the improvement of the economic growth of the country. As already stated, in Sudan most economic policies are driven by the need to serve the interests of the wealthy and the powerful for which the government has been accused due to offering economic opportunities to its clients and supporters. In this context, privatization has brought about some negative impacts on the situation of labor market by aggravating the predicaments of the urban poor and deprived a huge number of urban dwellers from chances of accessing income to pursue their livelihood. This is due to lack of transparency, rampancy of unsystematic trial and error approaches, absence of accountability, unfair opportunities given to political clients, absence of regulatory institutions, and paucity of appropriate mechanisms for compensating workers (Dagdeviren, 2006).

Although there is no available statistics at the national level on the total number of layoffs resulting from privatization, it seems that the outcomes of such process in terms of employment have been severely negative. According to Musa (2002), 5900 workers are believed to have been displaced following the liquidation of public agricultural corporations. The total lay off was not more than thirteen thousand and in the manufacturing sector, the employment share of the public sector dropped from around 25 per cent in the 1980 s to 10 per cent in recent years (Dagdeviren, 2006).

From the foregoing, one can clearly observe the link between externally-driven policies and the escalation of urban poverty in Sudan. Thousands of workers have been deprived of employment and became vulnerable to urban poverty. The compensation given to the laid-off workers were below their expectation and in most cases lost value in the slow process of getting it. Moreover, no training program was given to empower the retrenched workers to join the labor market and hence the negative socio-economic impact on their families. In adding salt to injury, the government introduced economic policies that are even harsher than the conditionalities imposed by the IMF and World Bank (Mahran, 2006) as discussed in the section below.

\section{Political economy and national land policy}

This section focuses on land use policy in relation to poverty in general and to the urban poor in particular. Changes in land use coupled with price liberalization should be held responsible for the impoverishment of rural and urban people in developing countries like Sudan. Having been colonized by the British, Sudan has inherited most of the British colonial legacy in accessing and managing land as a result of which they have two forms of land tenure: the legal right which is formally documented and officially accepted, and the customary or tribal 
land right. Customary right indicates that a member of the tribe can access land resources under the system of tribal homeland (no official documents). In this regard, the tribal or village leaders are responsible for offering and distributing land to both members of local communities and outsiders (El Hadary, 2007). This system still exists particularly in the rural areas although several legislations have been introduced to convert this it into a formally recognized legal right. Most if not all the customary communal owners, for different reasons, were unable in the past to register their lands (El Hadary, 2007) as legally belonging to them. This notwithstanding, local community members in Sudan continue to believe that the land is theirs while the government argues to the contrary by invoking pertinent provisions of the basis of the Unregistered Land Acts of ACT 1925, 1970, and 1984, which render holdings made in this manner as state land. As a result, there is always conflict between the government and the local communities especially when the government intends to set up a project. This means tribal rights only applies if the state doesn't claim the land for "development" purposes.

Since the colonial times all land Acts were amended to give power to the government to control land resources thereby undermining the historical rights of local people. For example, the Unregistered Lands Act of 1970 decreed that all unregistered land throughout the country to be registered as government property and granted the government the power of disposing of land as it saw fit and appropriate. Moreover, the Act entitled the government to use force in safeguarding "its land" and this has further been strengthened by the 1991-1993 amendment of the 1984 Civil Transactions Act which states that no court of law is competent to receive a complaint that goes against the interest of the state (Egemi, 2006). This Act was passed by the government under the pressure of the World Bank to serve the purposes of making Sudan "the breadbasket of the Arab world". As a consequence, large tracts of land were taken from the traditional owners under the pretext of new development and hence owners are left with no option than accepting compensation, if any. In Sudan, large-scale investments in irrigated areas and capital intensive mechanized rain-fed agricultural schemes were expanded at the expense of traditional tenure. Consequently, the total area under mechanized farms reached 17.2 million feddan, compared to 2.0 feddan in 1970, which is an increase of $606 \%$ (Egemi, 2006). As a result rural people not only lost the bulk of their land, which is the main source of their livelihood, but also received nothing in return from these projects. Therefore, the local people became net losers to the "new development" game while the "outsiders "such as foreign large-scale investors, government cronies, and big companies who made profit on the land through their factories, cash crops production and housing projects were the winners. In this vein, Ijaimi (2006) states that the overwhelming majority of mechanized scheme owners in Sudan are considered as "outsiders" in the major mechanized farming areas. It is astonishing to note that most of these beneficiaries are traders or government employees having no background in terms of engaging in agriculture. This proof that the establishment of big projects designated as "new development" is often driven by political decision that accords primacy to the interests of national and international policymakers.

Due to massive expansion of commercial agriculture (focusing on the production of cash crops) on the one hand and the proliferation of industrial enterprises in the rural areas on the other, large groups of rural people were pushed out from their land as a result of which their chances of averting poverty became slim. To cope with this harsh situation, some of the disaffected people resorted to engage in casual labor, rented their houses, sold their land, and survived on meager meals. Others were forced to migrate to the urban areas with the hope of securing their livelihood. Those who still practiced agriculture faced many difficulties and constraints especially after price liberalization and the complete withdrawal of the state from subsidizing agriculture. To meet the needs of obtaining agricultural inputs, farmers have to rely on banks for credit or individual lenders. The high interest rate and exorbitant arrangements of the credit system led to the problem of what is known today in Sudan as insolvency. Insolvency or MOSEREEN refers to a state of inability to meet the financial obligations to the banks or individual lenders. In the Alsahafa daily news paper issued on 21 March 2010 (number 5995), it was stated that around 8456 farmers were considered as having faced insolvency due to the liberalization policy, the role of the market, and the unfavorable banking and credit system subjecting some farmers to face such perils as imprisonment. In the final analysis Sudan, which was once classified as the breadbasket of the Arab World, became highly dependent on imported food due to tight government control over economic activities and the ensuing disincentives militating against the motivation to produce (Mahran, 2006).

\section{Urbanization and urban poverty in Sudan}

Due to the disparity in regional development and the inequality in the distribution of social services that are compounded by the collapse of traditional economy, large group of rural people have been forced to migrate towards the urban areas. As a result, unplanned urbanization or urban growth has expanded rapidly in Sudan. According to CBS (2008), around one third of the total population in Sudan is now living in the urban centers compared to the only 8 per cent on the eve of independence in 1956. Most of what was considered as sub-urban 
or rural land in the past has been completely absorbed by the rapid encroachment of the cities. The expansion of creeping urbanization into the rural areas entailed huge constraints on the infrastructure, agricultural production, housing demand, and provision of social services and pushed the poor further to settle and work on more marginal plots. Currently, there are seventy five urban centers in Sudan each of which hosts more than 20 thousand people. It is also worthy to note that twenty urban centers out of those mentioned above are inhabited by a minimum of more than one hundred thousand (see table 1 for more details).

Khartoum, the capital of Sudan, has witnessed tremendous increase in both spatial and demographic terms. The population of Khartoum in 2008 was $5,274,321$ of which 4,272,728 (81\%) is considered as urban and rest of $19 \%(1,001,593)$ rural. $53 \%$ of the total were males whereas $47 \%$ females (CBS, 2008). The horizontal expansion of the Greater Khartoum area has been quite remarkable with an increase of 48 times as large as it was in 1955. This due to unbalanced and inequitable regional development drives. For instance, Khartoum enjoys 73 per cent of the industries, 75 per cent of the industrial labor force, 67 per cent of electric power supply from the national grid, 85 per cent of commercial enterprises, 80 per cent of banking services, 85 per cent of industrial bank loans, 71 per cent of real estate bank loans, 65 per cent of the currency exchange market, 70 per cent of tax payers, 81 per cent of the taxes collected, 70 per cent of the hospitals and health centers, 65 per cent of medical doctors, and 80 per cent of the nurses of the total national share (Eltayeb, 2003).

Sudan has relatively experienced economic growth due to the discovery of oil and witnessed some degree of political stability as a result of the signing of Comprehensive Peace Agreement in 2005. Still due to unfair development policies and attendant practices, poverty remains one of the most serious problems and it has become the major concern of the national government. More than $90 \%$ of the population in Sudan is classified as poor of whom 50\% live in the urban areas (Mahran, 2006). Rural poverty in Sudan has increased from $64.2 \%$ in 1978 to $93.2 \%$ in 1992 while the increase of urban poverty was even more dramatic as this increased from $20.51 \%$ in 1978 to $84.4 \%$ in 1986 and reached 93.2 in 1992 (table 2). Officially the (CBS, 2010) indicates that $46.5 \%$ of the total population is under poverty line of whom $26.5 \%$ is urban and 57.5 is rural. The paramount increase of urban poverty is due to the factors mentioned early and to the existence of huge IDPs displaced by violence and conflict like in Darfur since 2003. It is estimated that in 2009, internally displaced persons number some 26 million, including 4.9 million in Sudan, 2.8 million in Iraq and 1.4 million in the Democratic Republic of the Congo (UNDP, 2009). Khartoum alone hosted around 2 million IDPs most of whom were from the South (Eltayeb, 2003).

Some facts about the socio-economic characteristics and Human Development Index of Sudan compiled by UNDP in 2007 are provided in table 3. Accordingly, all countries included in the HDI are classified into one of four clusters of achievement in human development: very high human development (with an HDI of 0.900 or above), high human development (with an HDI of 0.800 or above), medium human development (HDI of $0.500-0.799$ ) and low human development (HDI of less than 0.500). Moving from zero to one in the HDI measurement means a country has shown high level of human development. It is important to note that Sudan's HDI has improved by $1.12 \%$ annually, from 0.491 to 0.531 over the period 2000 and 2007 respectively. The Sudan HDI of 0.531 ranked $150^{\text {th }}$ places it at the bottom of the medium cluster countries thus coming after Haiti and above Ghana. This puts great difficulties on the country to meet the MDGs by 2015. Despite this, issues like food insecurity, growing informal sector, unplanned settlement and lack of social services, which are considered as urban poverty indicators, were found to be the reality in the country.

\section{Selected indicators of urban poverty}

\subsection{Food insecurity}

It is documented that in most of the urban areas in the developing countries including Sudan availability of food is not a major constraint. As is often the case, urban is considered as a place of consumption rather than production (Samat, 2010; Bakhit, 1994). Thus the availability of food in terms of quantity and quality is not a big issue but urban people mainly the poor ones have to worry about how to access and afford a healthy food. In this regard, enough money or a standard income is highly needed to address the concern in this regard. Samat (2010) in her study of poverty in Penang State in Malaysia mentions that income has a direct impact on the affordability and accessibility of food as social solidarity does not work in most of urban areas. In addition to having enough money, other factors should be considered in dealing with food accessibility. As stated by Bakhit (1994), geographical location, transportation system, type of occupation, monthly income, ethnicity, and loyalties to the government are important factors that must be taken into account. Currently, most if not all sections of the populations are facing huge difficulties in securing food in urban areas. This is due to the fact that their monthly income is too low to cover even one-third of the basic needs and thus securing food becomes a serious problem 
in Sudan. Up to now, the minimum salary that one gets is around 66 dollars compared to 285 dollars which is estimated as cost of living per month (MWSS, 2008). This means that only $23 \%$ of family basic needs are covered by making use of salaries obtained from employers like the government (table 4). The situation is even worse if one considers the recent estimates of daily expenditure, which is 4.4 dollars for an individual in urban and 3.5 dollars in rural areas (Ministry of welfare and social security, 2009). This means that a family of five needs 20 dollars per day or six hundred dollars per month to make sure that basic needs are met. This even beyond the capacity of university staff to afford where an assistant professor in Sudan gets US\$ 647 per month (table 6). This clearly explains why university staffs prefer to work outside the country. Recently one third of the staff in the department of geography left for Saudi Arabia in search of greener pasture.

Moreover, the urban poor have to spend more than half of their income for buying food. As indicated in table 5, a low-income family needs to spend at least $58 \%$ of its total income on food. This undoubtedly has a negative impact on other basic social services such as education and health. Currently, the predicaments of low-income earners are exacerbated skyrocketing of cost of living compared to the situation in the past. In this regard, the Ministry of Welfare and Social Security states that the real wages in 2008 and 2009 as compared to 2007 are equal to 87.5 and 84.5 respectively. In the light of this, there is enough reason why diseases related to food deficiency such Malaria, TB and malnutrition are still rampant mainly in many parts of Sudan and the less-developed areas in particular.

Table 5 indicates that there is a huge gap between the monthly salary one gets and the cost of basic needs including food. To bridge this widening gap, the urban poor resorts to income diversification through necessitating entire family members' engagement in income generating undertakings, seeking support from relatives, and reducing food consumption in terms of quantity and quality.

\subsection{Informal employment and settlement}

As already stated, most if not all rural migrants have come from agricultural background and are, therefore, not well trained to compete with limited chances in the urban labor market. This, together with the unfolding of privatization, has led most urban dwellers to join the informal sector for securing their livelihood. In the quest for maximum profit, employers in the form of factory or company owners tend to reduce the number of workers and concentrate on the most skilled and efficient. For an urban dweller who lacks the necessary skill and the requisite ability to compete in the labor market, the shortcut to pursue his/her livelihood is to join the informal sector although it is insecure and paying low wages with no prospects for obtaining pension or post-service compensation.

Although there is no reliable data regarding the total number of units and operators in the informal sector, it is obvious that this sector absorbs more than half of the urban populations in Sudan. In this connection, Eltayeb (2003) states that $65 \%$ of the urban dwellers in Sudan operate in the informal sector and such a high rate of involvement is due to fact that engagement in this field requires very little capital. Moreover, the fact that public sector employees are increasingly joining the sector because it is more rewarding financially in the face of a serious deterioration of their real incomes. In the same vein, UNDP (2006) states that the informal sector in Sudan accounts for about half of total urban employment and the distinction between the formal and informal sectors is getting blurred in Sudan at present. This is in view of the fact that in the past migrant seasonal workers secured temporary employment on the large irrigated farms, mechanized rain-fed agricultural schemes including and in non-agricultural activities in the small villages.

\subsection{Informal settlement}

With little money at their disposal to buy residential units in the urban areas and in the absence of a clear policy regarding housing, the urban poor have no choice other than living in shanty settlements and slums characterized by congestion and unhealthy conditions (Eltayeb 2003, World Bank 2005). In this regard, UNDP (2006) states that migrants from the rural areas might find employment in the informal sector where security for continued engagement is marginal. Hence they face considerable problems of getting modest accommodation thereby being forced to take refuge in ill-serviced and overcrowded informal settlements. Even the poor who manage to get a house in the inner city could be forced to join the slums and shanty settlements due to their inability to afford the ever-growing rent that is beyond their means. This is not the whole story on the light side of the moon; there are some people who can afford to buy more than one house not only in the outskirts but also in the central parts of the city. Ahmed (2008) is of the view that economic growth has not trickled down to the neediest sections of the population and the peripheral regions, which accentuates income inequality. Hence the benefits of growth are not been shared by all the citizens especially the poor. The aforementioned affirms that Sudan is one of the developing countries experiencing socio-economic and political inequality not only in urban areas but in 
the whole country at large. This is why most leaders of disaffected groups emphasize the need for justice, equity, and fair and equitable development at the top of their list of demands whenever issues of reaching at peace agreements are raised. Moreover, the prevalence of socio-economic inequality is further aggravated by the unfolding of rampant corruption including at the higher levels. According to the survey made by Transparency International in 2008 covering 47 countries, Sudan was ranked number $46^{\text {th }}$ next to Chad and followed by Somalia, which were ranked 45th and 47th respectively. In terms of prevalence of corrupt practices the weighted scores of the three most corrupt countries stood as 1.6, 1.5 and 1.1 out of ten for Chad, Sudan and Somalia respectively.

In the context of the theme of this paper, it is interesting to note that an employer may get nine thousand dollars per month while another gets only 20 dollars although both work for government (table 6). It is understandable that differences as acceptable gap could exist in salaries based on qualification, experience and educational status but variations exceeding twenty times are unacceptable and hence there is a need to reconsider and revise subject such alarming discrepancies. The persistence of such state of affairs could lead to polarization between social classes and eventually tear apart the existing social fabric. For example an engineer working in an oil company could earn in a time span of three years about 24 times the salary of a secondary school teacher who spends at least 25 years on his/her job. In the light of this, only few people can afford to own houses in the urban areas while the rest face difficulties even to rent a house in the remote areas (table 6). An Assistant Professor in Sudan earns a monthly pay of $\$ 700$, which hardly covers the costs of basic needs for half of the month. Hence owning a house for such professionals is farfetched.

Based on the characteristics of housing, it seems that members of the Sudanese middle class has gone and the remaining are either extremely rich that are few in number representing only $6 \%$ of society or the poor who represents the bulk of society has remained impoverished. Regarding building materials and the status of residential units in Khartoum only $6 \%$ have first and second class, $40 \%$ third, $10 \%$ newly planned, $40 \%$ squatter while $20.8 \%$ are made of concrete, $36.3 \%$ of bricks, $6.2 \%$ of brick and mud, $30.2 \%$ of mud, and others $6.2 \%$ (Eltayeb, 2003). Besides, $89.5 \%$ of the houses have ground floor, $4.3 \%$ two floors, $4.5 \%$ three floors, and $1.4 \%$ four floors. Those with more than four floors are only $0.3 \%$.

Due to the above mentioned constraints, the urban poor follow risky and long procedures to access planned houses and hence remain with two possibilities to resort to: either to rent and share a house and then apply for government land, or to join one of the squatter settlements. Ashwaee (slum) Ishash (huts), Jaloos (mud and grass) cartoon (cardboard), safeeh (tin-roofed) are some types of unplanned settlements. State policy towards such type of settlements is either to relocate dwellers in which case the "owner" gets title deed in remote areas or the second option is to demolish dwellings without paying any compensation. Eltayeb (2003) states that 12 out of the 17 squatter settlements have been relocated and the settlers got land title. According to the Rayaam daily newspaper issued on 13.07.2010 no 47428, the other option of demolishing and evicting dwellers also took place where three areas not far from the centre of the capital has been completely destroyed without compensation and even not informing the residents to adjust their situation. The story was that people in the three sites, namely Hasania Elsliet, Awlad Atah and Elahmda who lived for more than forty years and coped with the situation in the absence of basic services were removed.

\subsection{Lack of social services}

Living in unplanned settlement in places that are far from the urban centre has deprived large groups of the urban poor from accessing basic services such as education, health, water and electricity. In most cases the government is not willing to provide these settlements with basic services and left the matter to be handled by the residents. This due to the fact that such dwellers are labeled as illegal with no recognized house address and thus are classified as persons with no legal right to access services. UNDP (2006) stated that in the city government faces increased challenges in providing services to new settlement areas because the current size and scope of the city is far beyond what was planned in the past and the demand for municipal services and infrastructure development has far outpaced the government's capacity to provide. Whatever the case, the situation is indicative that the urban poor are not benefiting the available facilities that urban life requires. Within a few radius of the city centre, it is common to observe queues of children waiting to fetch water for their families. The valuable time a child mainly females spend for fetching is taken fore-granted as an important duty. Despite issues associated with water quality and availability, the price is so high compared to the piped networks that formal residents are required to pay for what they use. This has put remarkable pressure on other service (health and education) and became a heavy burden on families especially after the removal of state subsidies for covering costs of providing such public goods. Moreover, the urban poor have to devote more money to buy the services especially in these areas in order to attract workers like teachers and doctors to accept working in such a harsh 
condition (UNDP, 2006). In this regard, privatization has double effect on the urban poor: first it reduced opportunities in terms of getting job, and second it led to increase the price of services, mainly health and education. Since the introduction of user fees and complete withdrawal of the state from subsidizing services, the price paid to ensure access to services is increasingly becoming unaffordable for most if not all the poor people. A family with a child in a kindergarten needs one thousand dollars per annum just for school fees without including other expenses related to transportation and food. To consult a doctor, one must pay at least 20 dollars, which does not include costs for examination and medicine.

This section concludes by providing some figures regarding the inadequacies associated with providing social services. It was estimated that $25 \%$ of the population had no access to safe drinking water, $38 \%$ had no access to sanitation, 107 under five mortality rates, $76 \%$ of urban people live at a distance of $5 \mathrm{~km}$ from the nearest health centre, and only $35 \%$ of the urban population is covered by health assurance (Ahmed, 2008; MWSS, 2008). Although Sudan's performance appears to be better in providing some services, inequality between regions is discernable and striking. For instance, the adult literacy rate in the northern region are estimated at $86 \%$ for males and $72 \%$ for females, which are much higher than the figures for the south estimated as $37 \%$ for males and $12 \%$ for females (Ahmed, 2008).

\section{Poverty eradication policy in Sudan and lesson learnt}

The processes of privatization, market liberalization, and removal of State subsidies have adverse effects on the population in general and vulnerable urban groups in particular. Half of the urban population has been pushed into poverty due to the prevailing deficient policies. Several attempts have been made by the national government and civil society groups to address the victims of such policies in the urban areas. These include, among others, the solidarity fund (Takaful), the social insurance fund, the students support fund, the national retirement fund, the health insurance fund, and the social support fund (Zakat). In order to maintain the social balance, the government recently increased salaries, reduced the price of electricity, and provided micro-finance credit besides introducing a low-cost housing program. The overwhelming objective of all these support schemes is aimed at mitigating and alleviating urban poverty. Theses notwithstanding, however, the number of the urban poor is increasing and their situation is getting worse. Several issues need to be highlighted in order to answer why there is still poverty although various programs are adopted to tackle the problem. First and foremost, there is the lack of reliable data since there is no accurate household survey data about poverty until now. The number of people falling under the poverty line is not clearly known and it seems that the government states that only $4.3 \%$ earns less than one dollar a day for political reasons while others mention those under this category could be about $90 \%$. Secondly, measuring poverty is still a debatable matter in the sense that some believe in using income as indicator whereas others rely on the international standard of measurement. Thirdly, the problem of mismanagement and corruption particularly with regard to the procedure of providing fund is so complicated and time consuming. Not all money that is earmarked reaches the poor. For example, in 2008 , only $3 \%$ of the microfinance credit was accessed by the poor and the poor is required to show collateral, which is beyond the means at the disposal of the potential beneficiaries. Fourthly, there is lack of coordination between the various stakeholders involved in mitigating poverty. It is worth noting that each institution works separately and this may led to overlaps and waste of time and energy. Finally, the lack of political will and state commitment in taking serious action to improve the situation of both the rural and the urban poor is an important mitigating factor.

In view of the foregoing, the state has to put local people into focus rather than striving to fulfill the behest of powerful actors in the international system. These aforementioned factors clearly indicate the underlying reasons why urban poverty is mounting and will continue to do so unless remedial action is taken to address the challenges related to social inequality and regional disparity. It seems that poverty reduction is not listed as one of the top priorities of the incumbent regime in Sudan, which spends huge sums in expenditures related to defense and security rather than development. Mahran (2006) argues that with meager financial resources, expenditure on items such as defense and security and meeting foreign-debt obligations would undoubtedly take place at the expense of provision of economic and social services, particularly education and health.

The question to be raised here is whether Sudan is in a position to achieve the Millennium Development Goals and reduce poverty by half by 2015. As highlighted in this article, it seems that it is difficult, if not impossible, to achieve goals associated with poverty reduction especially under a situation where the country is ranked as second most corrupt. Hence there is an urgent need to address the problem of social inequality and the widening gap between the extremely rich and the extremely poor unless existing discrepancies in the country are narrowed or minimized. In this connection, Ali (2004) states that Sudan needs at least 28 years to achieve its stated goal of poverty reduction on condition that it registers a GDP growth rate of about 7 percent per annum. Ahmed (2008) 
also opined that Sudan's efforts to reduce diseases like malaria and tuberculosis are still far from achieving the targeted goals and more resources and effort are needed if these are to be effectively combated by 2015 .

\section{Conclusion}

Despite the relative economic growth rates achieved in Sudan, incidents of poverty are intensifying and spreading not only in the rural areas but also to a large extent in the urban areas. There are wide income and socio-economic development inequalities between regions, institutions, and even people. As a result, the country has experienced rapid urbanization due to massive migration that entailed huge difficulties in providing job opportunities, infrastructures, social services and housing. The vulnerable migrant groups were treated badly and in most cases in terms of not benefiting from what the city should provide to urban dwellers in term of services and income. To cope with this lamentable situation, the urban poor join the informal sector and are forced to live in slums. Despite efforts made to eradicate poverty, the number of the urban poor is still steadily mounting.

This paper has shed light on some aspects of the pertinent national and international policy settings that have led to the deepening of urban poverty in Sudan. Several responsible factors like SAP, privatization and land use policy have been investigated to measure the impact on urban poverty. These policies are formulated to serve the interests of the domestic power elite and the preferences of external policy makers. Due to skewed and unequal power relations between the rich and poor on the one hand and between south and north on the other, developing countries are forced or induced to accept and apply whatever policy that comes from the west. This will continue to persist unabated unless developing countries manage to find ways to empower themselves and their citizens.

The findings of the study with regard to the subject in question show that developing countries including Sudan are experiencing rapid urbanization growth due to massive migration where urbanization is not well developed to handle such phenomenon. Lack of urban employment opportunities has led to increase of engagement in the informal sector and thus putting huge pressure on the already existing limited urban services and infrastructural facilities. The mechanisms that the urban poor adopted to cope with such condition include, selling or renting land on the part of urbanites, living in unhealthy environment, diversification in income generation, division of residential units to accommodate businesses, and undertake small economic activities along the main roads. Currently issues like urban poverty, slum dwelling, ever-increasing engagement in informal sectors, and fuzzy boundaries have become a headache for urban planners to handle and dealt with and it is too difficult if not impossible to achieve the requirement of MDGS by 2015.

\section{References}

Ahmed, M. M. (2008). Can the Sudan Achieve the MDGs Given its past and present Expenditures Allocation Pattern? Bergin: CMI

Ali, A. A. (2004). Structural Adjustment Programmes and Poverty in Sudan. Paper presented at the Arab Research Centre.

Alsahafa newspaper. (2010, 5995 on 21 March 2010).

Babiker, M., \& Pantuliano, S. (2006). Addressing chronic livelihoods vulnerability in Red Sea State. Red Sea Sudan: OXFAM GB.

Bakhit, A. H. (1994). Availability, Affordability and Accessibility of Food in Khartoum. GeoJournal 34(3 ), 253-255. doi:10.1007/BF00813927, http://dx.doi.org/10.1007/BF00813927

Central Beruau of Statistics Sudan. http://www.cbs.gov.sd/ (2008).

Central Beruau of Statistics Sudan. http://www.cbs.gov.sd/ (2010).

Dagdeviren, H. (2006). Revisiting privatization in the context of poverty alleviation: the case of Sudan. journal of international development, 18, 469-488.

Egemi, O. (2006). Land tenure in Sudan challenges to livelihood security and social peace. In G. E. El Tayeb (Ed.), land issue and peace in Sudan. Khartoum-Sudan: Sudan Environment Conservation Society.

Egemi, Omer, A. (1994). the political ecology of subsistence crisis in red sea hills, Sudan, university of Bergen, Norway.

El Hadary, Y. A. (2007). Pastoral Adaptation and Socio-Economic Transformations in the Butana Area-Al Gedaref State, Sudan. University of Khartoum, Khartoum.

El Tayeb, G. E. (2003). Understanding slums: The case of Khartoum, Sudan. London Earthscan: UN-Habitat. 
Ijami, A. (2006). Mechanized farming and conflict in Sudan. In G. E. El Tayeb (Ed.), land issue and peace in Sudan. Khartoum-Sudan: Sudan Environment Conservation Society.

MAHRAN, H. (2006). Public policy and poverty reduction in Sudan, 1971-2002. Paper presented at the Public Policy and Poverty Reduction in the Arab Region.

Ministry of Welfare and Social Security. (2008). http://www.wagescouncil.gov.sd

Ministry of Welfare and Social Security. (2009). http://www.wagescouncil.gov.sd

Ministry of Welfare and Social Security. (2010). http://www.wagescouncil.gov.sd

Musa, E. A. (2000). Sudan Structural Adjustment Programme (Ssap): Some Implications for Laboring the Formal Sector. African Administrative Studies, 56.

Musa, E. A. (2002). The Impact of Public Enterprise Reforms on the State Budget in Sudan. Paper presented at the Administration for Development Tangier Morocco.

Philip F, K. (1998). The politics of urban-rural relations: land use conversion in the Philippines. Environmental and Urbanization, 10 (1).

Rayaam newspaper. (2010, 47428 on 13.July.2010).

Samat, N. \& et al. (2010). Application of geographic information system in identifying deprived areas. Paper presented at the 7th international Malaysian studies conference.

Samat, N. (2002). A geographic information system and cellular automata spatial model of urban growth for Penang State, Malaysia. University of Leeds, Leeds UK.

Tacoli, C. (1998). Rural urban interaction: a guide to the literature. Environmental and urbanization, 10 (1).

Todaro, M. 1989. Economic Development in The Third World, 4th edition, Longman, New York and London.

Transparency, O. O. (2009). Corruption Perceptions Index 2009 Regional Highlights: Sub-Saharan Africa.

UNDP. (2006). Macroeconomic Policies For Poverty Reduction: The Case Of Sudan Khartoum Sudan.

UNDP. (2009). Human Development Report, Overcoming barriers: Human mobility and development.

UNESC. (2007). Facing the Challenges of Urbanization and Urban Poverty in Asia and the Pacific in Urban poverty and the Working Poor. Bangkok Thiland.

World Bank. (2005). the Dynamics of Global Urban: Expansion Transport and Urban Development. Washington D.C. 
Table 1. The Situation of Urbanization in Sudan 1973-2008

\begin{tabular}{|l|l|l|l|l|l|}
\hline No. & Name & $\mathbf{1 9 7 3}$ & $\mathbf{1 9 8 3}$ & $\mathbf{1 9 9 3}$ & $\mathbf{2 0 0 8}$ \\
\hline 1 & Omdurman & 299,399 & 526,192 & $1,271,403$ & $1,849,659$ \\
\hline 2 & Al-Khartum & 333,906 & 473,597 & 947,483 & $1,410,858$ \\
\hline 3 & Al-Khartum Bahri & 150,989 & 340,857 & 700,887 & $1,012,211$ \\
\hline 4 & Nyala & 59,583 & 111,693 & 227,183 & 492,984 \\
\hline 5 & Port Sudan & 132,632 & 206,038 & 308,195 & 394,561 \\
\hline 6 & Juba & 56,737 & 84,377 & 125,000 & 372,413 \\
\hline 7 & El Obeid & 90,073 & 137,582 & 229,425 & 345,126 \\
\hline 8 & Kassala & 99,652 & 141,429 & 234,622 & 298,529 \\
\hline 9 & Wad Madani & 106,715 & 145,015 & 211,362 & 289,482 \\
\hline 10 & El-Gedaref] & 66,465 & 116,876 & 191,164 & 269,395 \\
\hline 11 & Al-Fashir & 51,932 & 84,298 & 141,884 & 217,827 \\
\hline 12 & Kosti & 65,404 & 89,135 & 173,599 & 213,080 \\
\hline 13 & Waw & 52,750 & 58,008 & 84,000 & 151,320 \\
\hline 14 & El Duein & 18,457 & 21,666 & 73,335 & 137,103 \\
\hline 15 & Ad-Damazin & 12,233 & 27,591 & 71,821 & 136,788 \\
\hline 16 & El Geneina & 35,424 & 55,480 & 92,831 & 134,264 \\
\hline 17 & Malakal & 34,894 & 33,737 & 72,000 & 126,483 \\
\hline 18 & Rabak & 18,399 & 26,693 & 59,261 & 123,890 \\
\hline 19 & Sennar & 28,546 & 42,803 & 72,187 & 123,158 \\
\hline 20 & Atbarah & 66,116 & 72,836 & 87,878 & 112,021 \\
\hline
\end{tabular}

Source: Central Bureau of Statistics-Sudan (2008) calculated by the authors

Table 2. Percentage of Poverty in Rural and Urban area in Sudan (1968-1992)

\begin{tabular}{|l|l|l|l|l|l|}
\hline Type & $\mathbf{1 9 6 8}$ & $\mathbf{1 9 7 8}$ & $\mathbf{1 9 8 6}$ & $\mathbf{1 9 9 2}$ & $\mathbf{2 0 1 0}$ \\
\hline Urban & 15.9 & 20.5 & 52.9 & 84.4 & 26.5 \\
\hline Rural & 62.9 & 64.2 & 83.1 & 93.2 & 57.5 \\
\hline The total & No data & 54.3 & 77.8 & No data & 46.5 \\
\hline
\end{tabular}

Source: Ali 1994 cited in Maharn 2006 and CBS 2010 
Table 3. Selected Indicators of Human Poverty for Sudan in the Year 2007

\begin{tabular}{|l|l|l|}
\hline \multirow{2}{*}{ Issues } & Sudan \\
\cline { 2 - 3 } & Rank & Degree \\
\hline HDI value & 150 & 0.531 \\
\hline Life expectancy at birth & 142 & 57.9 \\
\hline GDP per capita (PPP US\$) & 137 & 2086 \\
\hline Immigrant destination - \% Total population & 128 & 1.7 \\
\hline Adult literacy rate (\% ages 15 and above) & 126 & 60.9 \\
\hline Human poverty index & 104 & 34 \\
\hline Probability not surviving Age 40\% & 123 & 23.9 \\
\hline Adult illiteracy rate (\%ages 15 and above) & 126 & 39.1 \\
\hline People not using improved water source (\%) & 113 & 30 \\
\hline Children underweight for age (\% aged under 5) & 132 & 41 \\
\hline Emigration rate (\%) & 149 & 1.7 \\
\hline
\end{tabular}

Source: Human Development Report 2009-HDI rankings

Table 4. Minimum Wages in Dinnar and Dollar in Sudan (1995-2009)

\begin{tabular}{|l|l|l|l|l|l|l|l|l|}
\hline Year & $\mathbf{1 9 9 5}$ & $\mathbf{2 0 0 0}$ & $\mathbf{2 0 0 3}$ & $\mathbf{2 0 0 4}$ & $\mathbf{2 0 0 5}$ & $\mathbf{2 0 0 6}$ & $\mathbf{2 0 0 8}$ & $\mathbf{2 0 0 9}$ \\
\hline Minimum wages & 25.00 & 40.25 & 75.00 & 125.00 & 125.00 & 150.00 & 165.38 & 165.38 \\
\hline In dollar US\$ & 10 & 16 & 30 & 50 & 50 & 60 & 66 & 66 \\
\hline
\end{tabular}

Source: Ministry of welfare and social security 2009http://www.welfare.gov.sd/

Table 5. Less and High income the Family Expenditure Items 2008

\begin{tabular}{|l|l|l|}
\hline Item & Less Income Expenditure \% & High Income Expenditure \% \\
\hline Food and drinks & 58.1 & 42.3 \\
\hline Housing & 30.3 & 14.7 \\
\hline Clothes shoes & 5 & 5 \\
\hline Health and medicine & 1.2 & 1.7 \\
\hline Transport & 4 & 31 \\
\hline Education & 1.4 & 5.3 \\
\hline
\end{tabular}

Source: ministry of welfare and social security 2009 http://www.welfare.gov.sd/

Table 6. Monthly Salaries in Selected Sector 2008

\begin{tabular}{|l|l|l|l|l|l|l|l|l|l|l|}
\hline $\begin{array}{l}\text { Salary / } \\
\text { Sector }\end{array}$ & $\begin{array}{l}\text { General } \\
\text { education }\end{array}$ & US\$ & $\begin{array}{l}\text { Secondary } \\
\text { education }\end{array}$ & US\$ & $\begin{array}{l}\text { Higher } \\
\text { education }\end{array}$ & US\$ & Communication & US\$ & Oil & US\$ \\
\hline Minimum & 306 & 122 & 317 & 126 & 680 & 272 & 1254 & 501 & 734 & 293 \\
\hline Medium & 600 & 240 & 566 & 226 & 1618 & 647 & 3215 & 1286 & 2362 & 944 \\
\hline Maximum & 850 & 340 & 813 & 325 & 2319 & 927 & 6353 & 2541 & 21620 & 8648 \\
\hline
\end{tabular}

Source: wages council 2009 http://www.wagescouncil.gov.sd 


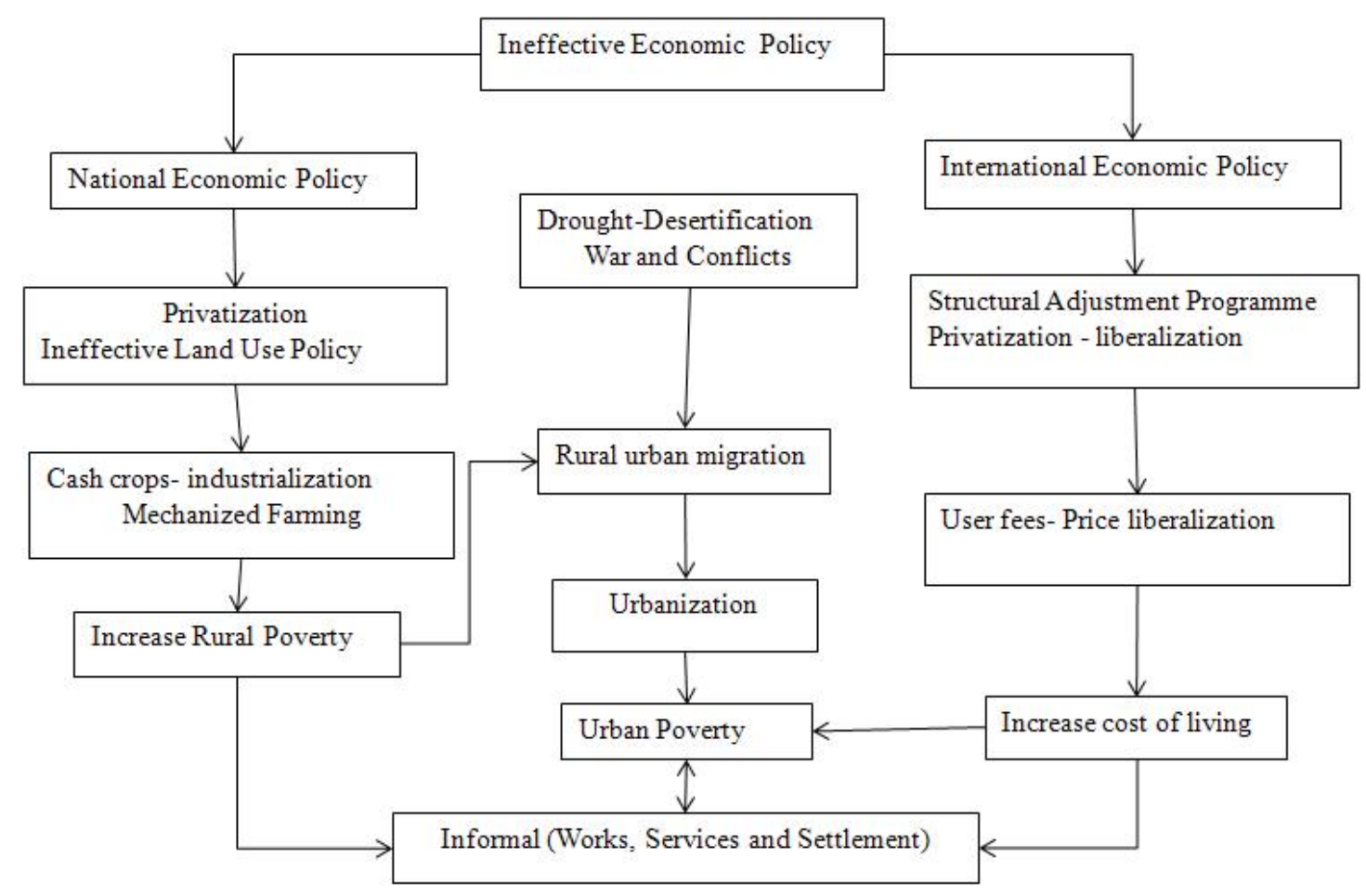

Figure 1. The Schematic Illustration of Urban Poverty 